\title{
Collaborative Entrepreneurship: A Smart Solution For Small Business To Survive
}

\author{
Elsye Tandelilin ${ }^{1}$, Johny Rusdiyanto ${ }^{2}$, Muhammad Aan Auliq ${ }^{3}$ \\ \{elsye.tandelilin@gmail.com $\left.{ }^{1}\right\}$
}

\author{
Program Studi Manajemen Fakultas Bisnis dan Ekonomika Universitas Surabaya ${ }^{1,2}$ \\ Program Studi Elektro - Fakultas Teknik Elektro - Universitas Muhamdiyah- Jember ${ }^{3}$
}

\begin{abstract}
Entrepreneurship is also a key factor that enables a country to grow economically and determine sustainable business activity. The concept of entrepreneurship is collaborative although interesting but not yet widely understood by business people in developing countries. The paper aims is to answer the research questions what determines collaborative entrepreneurship among small business in the Watu Wungkuk and Mranggon Lawang villages. This research uses a field research approach (qualitative research) in which researchers directly observe and participate in a small-scale social condition. Researchers also interact directly face to face with "real people" in a natural social order. The results showed that individual, community and institutional need to be incorporated in order to understand the concept among small business. When doing business individually, the small business gets less beneficial than doing business collaborative. The role of the government to support collaborative entrepreneurship is needed especially related to licensing, capital and improving human resource competencies
\end{abstract}

Keywords: Collaborative Entrepreneurship, Small Business

\section{Background}

Entrepreneurs are considered as a tool to maintain sustainability and business growth. Entrepreneurship is also a key factors that enable a country to grow economically and determine sustainable business activity (Parker, 2009) The fact shows that small business contribute around $70-99 \%$ to job creation in worldwide and create a large portion of national income (Hong, et al., 2012). In the most developing countries a small increase in small business productivity can result in a substantial increase in GDP (Anon-Higon, et al., 2014). But on the other hand, the level of small business mortality is also quite high. The research conducted by Heidrich \& Tiwary (2013) focuses more on the obstacles that affect the ability of small business to survive in the market and compete with larger companies. The practical solution for the above conditions is make collaborate among small business and this is still rarely studied. The number of collaborations among small business is not much done because of the assumption that the collaboration will endanger the autonomy of each small business. Therefore studying collaborative activities is more viewed in understanding as small-scale cooperation.

Collaboration can be done between small business and large companies or among small business. Research conducted by Alvarez \& Barney, 2001; Nakos, et al., 2014 cited by Rezazadeh.A (2017) showed that small business tends to lack bargaining power in the practice of collaboration with large companies and the results will reduce the benefits of the collaboration. As an alternative, small business can be encouraged to collaborate with other 
small business, because one of driving force of the collaboration success is the similarity or linkage among small business (Chun \& Mun, 2012). One of the benefits of collaboration among small business is the creation of innovation and is considered as one of the determine key for survive, grow and sustain (Pelser, 2014; Pullen et al., 2012). Innovation is part of collaborative entrepreneurship in developing countries when people together intend to encourage social change.

The entrepreneurship thinking shift has been linked to increased media attention aimed at innovation (Brem and Wolfram, 2014), so it is feasible to do more research focusing on collaborative entrepreneurship in developing countries because it deals with innovation and the creation of new business ventures.

The small businesses selected in this study were the shallots business. Based on the observation, interview and involvement in community activities for 3 years in those villages, several problems faced by citizens were revealed, namely:

(1) Mind set of small business entrepreneurs who seek personal gain without wanting to share positive knowledge among small businesses. (2)The nursery system is still in traditional way which consume time and costs. (3)The fried shallots are the sole processed / derivative product, because farmers do not have enough knowledge and technology to process shallots into other value-added products. (4)There are no groups / institutions that manage shallot products includes technology, packaging, and marketing so that the pace of community economic development becomes sluggish. (5)The frying process of shallots is very simple and conventional. Consequently, it contains a lot of oil and not crispy. (6)Packaging is still simple so that the appearance is very unattractive. The size of the packaging also does not vary (only packages per $1 \mathrm{~kg}$ ), does not have a permit for a Home Industry Product (PIRT) and does not have a brand. (7)Sales system for both (raw and fried shallot) products with a bonded system and sold to middlemen. (8)There is no product standardization, no guidance and quality control (9)The orientation of small business people is still in short-term, they don't want something complicated and orientate to make money immediately.

The paper aims is to answer the research questions as follows: What determines collaborative entrepreneurship among small business in the Watu Wungkuk and Mranggon Lawang villages? This research is expected to contribute to the development of collaborative entrepreneurship concepts, especially at the small business levels and help overcome the problems of them.

\section{Literature Review}

\subsection{Collaborative entrepreneurship}

The concept of collaborative entrepre-neurship is based on the creation of something of economic value arising from new ideas created together that arise from sharing information and knowledge (Gupta and Govindarajan, 2000; Kenney and Mujtaba, 2007). Collaborative entrepreneurship is a process that involves the use of networks to convey better decisionmaking activities when in business collaboration (Ratten, 2014). Motivation for entrepreneurship in each developing country varies. Some are motivated by economic factors and some are due to social interests. Classical entrepreneurial theory argues that financial gain is the main motivation for business ventures (Fauchart and Gruber, 2011). In addition to financial reasons, even today there is a lot of motivation to do business because of nonfinancial reasons. Entrepreneurs in developing countries face many challenges including generating new ideas that have the potential to be developed, and some of them may not be financially viable in the long run but still be carried out for social reasons (Dana, 1996). 
Entrepreneurialism aims to advance society and improve people's lives by assuming risk when something of value is created (Schneider, 2013). Entrepreneurship coaching is important for developing countries because it connects business leaders, political parties and the community together to encourage the creation of an entrepreneurial culture. This is important for the nation's economic performance and has a positive impact by changing the way of life and behavior of the community (Ratten, 2014). Entrepreneurship is a mechanism so that opportunities are developed in a natural and communal environment that combines economic and social benefits (Patzelt and Shepherd, 2011). Personal economic benefits are a key motivator of sustainable entrepreneurship. In developing countries, personal economic benefits must be linked to the environment and social benefits to encourage entrepreneurial development. Ratten (2014) suggests an ensemble approach, an approach that collaborates a number of different people and organizations. If linked to entrepreneurship, collaboration can occur consciously or unconsciously depending on the individuals and organizations involved (Gilmore, 2011).

The entrepreneurial collaboration process involves a partnership that develops from two or more parties that aim to create profitable results. Collaborative partnerships in developing countries can create new practices and structures that involve different stakeholders. Insights from collaborative entrepreneurship in developing countries discussed in this paper offer some practical recommendations. This includes the inclusion of cultural and social services that can encourage business collaboration. The adoption of a collaborative entrepreneurial perspective in developing countries can provide important insights into how partnerships can bring different resources together to create business opportunities.

\subsection{Key Factors of Collaborative Entrepreneurship}

Collaborative entrepreneurship is formed by the tendency of individuals and communities to collaborate in business. The characteristics of collaborative entrepreneurship are related to financial management, business acumen and interpersonal communication. This shows that to achieve collaboration, there must be a relationship between the business ambitions of the organization and the business ambitions of the community (Ratten, 2014). Recognition of entrepreneurial collaboration is based on the idea that knowledge and motivation will be better together than alone (Patzelt and Shepherd, 2011).

The key factors of collaboration entrepreneurship are:

\section{a. Individual level of entrepreneurialism}

According to Fauchart and Gruber (2011) entrepreneurship gives individuals the ability to pursue personal dreams and desires in the formation of business cooperation. This shows that entrepreneurial activity is related to meaning because it comes from individual self-awareness. Entrepreneurial competencies such as lateral thinking, intuition and knowledge are needed in business, also in entrepreneurship collaboration competencies such as creativity, leadership and communication are needed. Collaboration will provide various benefits such as helping in market information, information on changing business conditions, assisting in marketing channels and so on.

\section{b. Community level of entrepreneurialism}

Social problems in developing countries include changes in the communal environment, driven by cultural change, the meaning of natural and communal influences entrepreneurial opportunities (Patzelt and Shepherd, 2011). The interaction between entrepreneurial activities and communal activities has been known as a community-based business concept which 
shows that a community pursues a common goal to achieve business goals. Community-based companies help improve economic conditions in developing countries by creating solutions to social problems (Peredo and Chrisman, 2006). In developing countries, people, the economy and society join together to encourage entrepreneurial activities that support the society. The behavior of people in developing countries is more likely to be collective so that a collective approach to doing business allows the community to focus together on business opportunities (Ratten, 2014)

\section{c. Institutional level of entrepreneurialism}

The government is a regulatory agency in developing countries that are the source policies and provide programs that offer information about business practices. Capital difficulty is a problem that often occurs in small businesses because they lack access to banking and other financial institutions. Therefore, one of the roles of the government in supporting the development of entrepreneurship is through funding and infrastructure support (Ratten, 2014)

\section{Methods}

This research uses a field research approach. Field research is a qualitative research in which researchers usually directly observe and participate in a small-scale social condition. Researchers can also interact directly face to face with "real people" in a natural social order (Neuman, 2014: 432). Field research requires direct conversations and observations of the people studied. The process of personal interaction can occur for months or even years because researchers want to know the lives of people / community and history about their lives, hobbies, habits, hopes, fears and so forth. According to Kenneth D. Bailey (1994: 254) the term field study is a term that is often used in conjunction with the term ethnographic study (ethnographic study or ethnography).

Lawrence Neuman (2014: 435) also explained that field research is also often called ethnography or participant observation research. However, according to Neuman ethnography is only an extension of field research. Ethnography redefines how field research must be carried out. Besides offering interesting things in this approach, field research is also time consuming, emotionally draining, and sometimes physically dangerous. Field research is very appropriate when research questions include learning about, understanding, or describing the interactions of a group of people. The main characteristic is the direct and in-depth involvement of researchers in the form of direct contact with resource persons / actors / participants, theoretical / literary studies only as initial information (not the absolute basis for making research questions), and research results that are in accordance with the perpetrator's experience.

In this study, researchers wanted to examine the ways of thinking, behaving, interacting, culture, and how to do business from people in the villages of Watu Wungkuk and Mranggon Lawang, Dringu Sub-District, Probolinggo District. The use of this method allows accurate and definite results, due to the involvement of researchers for three years with the communities in the two villages. Field research allows researchers to explore broadly social conditions, subcultures and aspects of social life. Referring to Yin (2000) and Eisenhardt (1989), this research data collection method uses multiple sources. Multi data sources are needed to support the validity and reliability of the data obtained. Fields research methods used in this study are guided by the development of theory and sampling time, situation, type 
of event, location, type of person or context of interest. Reliability in field research is done through internal consistency and external consistency (Neuman, 2014: 247-248).

\section{Results and Discussion}

\section{a. Individual level}

Based on observation, interviews and involvement with community activities, various problems experienced by small business in Watu Wungkuk and Mranggon Lawang villages were explored. To overcome mind set problems of small business, various motivational trainings were conducted to change their mind set, but the changes were not seen as significant. The majority of small business mind sets are still individualized. As a result each individual seeks personal gain and often neglects community interests. This can be seen from the way the small business manage their businesses in agriculture and processed products (fried shallots) which are more likely to rely on middlemen as end users who have full bargaining power in determining the selling price. This condition has been running for a long time and is considered as a fairness, because people think not to be complicated in the matter of marketing the final product. In the agricultural sector, successful business people are reluctant to share their success with other business people. The agricultural small business should have uniform cultivation methods and cultivation patterns to avoid the spread of plant pests. In facts each of the entrepreneurs has his own way. Consequently crop failure often results in huge losses for agriculture small business.

\section{b. Community Level}

When observing and understanding the reasons why small enterprises in Watu Wungkuk and Mranggon Lawang are more oriented towards individual interests, the researchers made various efforts to overcome these conditions, among others by holding various trainings related to mind set and entrepreneurship collaboration. Then do a personal approach to persuade business people to form groups that aim for common interests. Finally a farming group was formed with the name "HARAPAN JAYA 1" and a group of shallots frying under the name "NURUL HIDAYAH". These groups are encouraged to make mutually beneficial agreements and hold regular meetings to discuss emerging issues. The collaboration resulted in various agreements including agreements related to cropping patterns, fertilizer use and pest control. Regarding the issue of nurseries, collaborations with a number of businesses were carried out to create a pilot project using appropriate technology (TTG) that adopted a system blower on the AC cooler, but for seedlings using heat. This system technically brings various benefits such as being able to reduce the level of loss of farmers because there are no red onions burned, the shallot seeds produced are cleaner, reduce rat pests, warehouse capacity can be used optimally and reduce the use of labor, because there is no need to maintain coal fire in a nursery house. In addition, the nursery period is shorter, which is 45 days while traditional nurseries require a minimum period of 60 days. So there is an efficient time of 15 days in one period of nursery.

The shallot frying group made several agreements, among others, changes the packing size from $1 \mathrm{~kg}$, into the various sizes ( 1 ounce, $1 / 4 \mathrm{~kg}$, and $1 / 2 \mathrm{~kg}$ ). The thickness of plastic size (packing) is at least 0.8 and must have a cover clip, not using bulk oil, use 200 grams of flour for 1 kilo of raw shallot, spinner time is 10 minutes. It was also agreed that the brand name for fried shallot is ARMOS which comes from the Madurese language, meaning tasty or crispy. In addition, an agreement was also made regarding the selling price. To change the mind set and the behavior of shallot fryer, each member is invited to visit the packaging house in Dringu- 
Probolinggo district to see various types of packaging and their functions, also consult with the experts there. The mind set change can be seen from the behavior of shallot fryer use spinner to reduce oil before the product is packaged. Quality plastic shops and packaging houses begin to be visited and purchase the standard plastics packing.

Collaboration among small business merges ideas and creativity that make their business better. This is in accordance with the results of the research put forward by Dana (2004) that in a collaborative entrepreneurship approach, individual skills are integrated in a group activity to make the innovation process bigger. At the same time the collaboration helps solve the problems faced by small business in the villages of Watu Wungkuk and Mranggon Lawang. The results of this study are in line with research conducted by Peredo and Chrisman (2006) which shows that community-based enterprises help improve economic conditions through the creation of solutions to social problems.

\section{c. Institutional Level}

Forming collaborative entrepreneurship is easier than keeping the collaboration going well. Government support through various agencies starting from the village, sub-district, provincial and capital levels needs to be done. Collaboration between businessmen in agriculture is getting enough attention from the government at various levels, because it is related to the level of food productivity in Indonesia. Therefore, government assistance to the agricultural sector is quite a lot every year, such as fertilizer, pest control, seeds, training and so on. The existence of the brand began to be realized, so the fried shallot businessmen there agreed to provide a brand for derivative products produced in each village. For the village of Mranggon Lawang using the name "Keysia" and in the village of Watu Wungkuk use the brand "Armos". The results of the training on derivative product development began to be responded to, and developed by shallot entrepreneurs. This can be seen from the emergence of the shallot snack with a spicy taste in various levels and various sizes. However, license acquisition of home industry product (PIRT) is still administrative constraints, although the relevant government agencies provide consultation support to business people who want to take care of their permits. In terms of marketing, especially online marketing, the government also helps through various agencies such as small, medium enterprises service.

The institutional program of village-owned enterprises (BUMDES) is one of the official government programs to help small business in the villages to survive and develop. Financial assistance through this institution is very much taken care of by the government which is passed down through the village budget (AD) every year. Even the government works with national banking institutions such as Bank Negara Indonesia / BNI 46, to provide soft loans to small business in 2 forms: (1) Micro "KUR" with a total loan of IDR. 10-25 million without collateral. (2) Retail KUR with a loan of IDR $>25-500$ million with a guarantee. The government program due to the capital difficulties of small business and they have limited banking access to borrow. This is consistent with the study of Whincop (2001) who said that obtaining access to funding can be difficult for businesses because of the reluctance of banks to provide loans to new businesses that have not been proven successful. Collaboration among small businesses and village officials resulted in the idea of forming a village-owned enterprise (BUMDES) which was successfully established on July 16, 2018 under the name "BUMDES JAYA ABADI" which was legalized through village decrees. The BUMDES had a role to increase the income and welfare of rural communities.

\section{Conclusions}


The concept of entrepreneurship is collaborative although interesting but not yet widely understood by business people in developing countries. The conceptualization of collaborative entrepreneurship in this paper indicates that individual, community and institutional need to be incorporated in order to understand the concept among small business. When doing business individually, the small business gets less beneficial than doing business collaborative. Governments can use the concept to assess the community orientation of their business community in order to improve social business performance.

\section{REFERENCES}

1. Añón-Higón, D., Manjón-Antolin, M., Mañez, J.A. and Sanchis-Llopis, J.A. (2014) 'Does R\&D protect SMEs from the hardness of the cycle? Evidence from Spanish SMEs (1990-2009)', International Entrepreneurship and Management Journal, Vol. 11, No. 2, pp.361-376.

2. Brem, A. and Wolfram, P. (2014) 'Research and development from the bottom up-introduction of technologies for new product development in emerging markets', Journal of Innovation and Entrepreneurship, Vol. 3, No. 9, pp.1-22.

3. Chun, H. and Mun, S.B. (2012) 'Determinants of R\&D cooperation in small and mediumsized enterprises', Small Business Econo-mics, Vol. 39, No. 2, pp.419-436.

4. Dana, L. (1996) 'Small business in Mozam-bique after the war', Journal of Small Business Management, Vol. 34, No. 4, pp.67-71

5. Eisenhardt, K. and Schoonhoven, C. (1996), "Resource-based view of strategic alliance formation: strategic and social effects in entrepreneurshipfirms",Organization Science, Vol. 7 No. 2, pp. 136-50

6. Fauchart, E. and Gruber, M. (2011) 'Darwinians, communitarians, and missionaries: the role of founder identity in entrepreneurship', Academy of Management Journal, Vol. 54, No. 5, pp.935-957.

7. Gilmore, A. and Carson, D. (2011) 'Teaching and research in small business enterprise marketing', in Hines, D. and Carson, D. (Eds.): Innovative Methodologies in Enterprise Research, Edward Elgar, Cheltenham.

8. Gupta, A.K. and Govindarajan, V. (2000), "Knowledge flows within multinational corporations", Strategic Management Journal, Vol. 21 No. 4, pp. 481-510

9. Heidrich, O. and Tiwary, A. (2013) 'Environmental appraisal of green production systems: challenges faced by small companies using life cycle assessment', International Journal of Production Research, Vol. 51, No. 19, pp.5884-5896

10. Heidrich, O. and Tiwary, A. (2013) 'Environmental appraisal of green production systems: challenges faced by small companies using life cycle assess-ment', International Journal of Production Research, Vol. 51, No. 19, pp.5884-5896.

11. Hong, P., Huang, C. and Li, B. (2012) 'Crisis management for SMEs: insights from a multiple-case study', International Journal of Business Excellence, Vol. 5, No. 5, pp.535553.

12. Kenney, M. and Mujtaba, B. (2007), "Understanding corporate entrepreneur-ship and development: a practitioner view of organizational intrapreneurship", Journal of Applied Management and Entrepreneurship, Vol.12 No. 3, pp. 73-88

13. Neuman W.Lawrence, 2014, Social Research Methods : Qualitative and Quantitative Approaches, Seventh Edition, Pearson

14. Patzelt, H. and Shepherd, D.A. (2011) 'Recognizing opportunities for sustainable development',Entrepreneurship Theory \& Practice, May, Vol. 35, No. 4, pp.631-652. 
15. Peredo, A.M. and Chrisman, J.J. (2006) 'Toward a theory of community-based enterprise', Academy of Management Reviews, Vol. 31, No. 2, pp.309-328.

16. Pelser, T. (2014) 'The affect of innovation strategies and their connect to company performance', Mediterranean Journal of Social Sciences, Vol. 5, No. 9, pp.60-68.

17. Pullen, A.J., Weerd-Nederhof, P.C., Groen, A.J. and Fisscher, O.A. (2012) 'Open innovation in practice: goal complementarity and closed NPD networks to explain differences in innovation performance for SMEs in the medical devices sector', Journal of Product Innovation Management, Vol. 29, No. 6, pp.917-934.

18. Rezazadeh Arash, (2017), The contribution of business model innovation to collaborative entrepreneurship between SMEs : a review and avemues for further research, International Journal Business and Globalization., Vol.18, No.1.2017

19. Ratten Vanessa, Collaborative entrepreneurship and the fostering of entreprenurialism in developing countries, Int.J. Social Entrepreneurship and Innovation., Vol.3, No. 2, 2014

20. Schneider, R.C. (2013) 'Entrepreneurialism and sport leadership: somelessons for the Balkans', in Ramadani, V. and Schneider, R.C. (Eds.): Entrepreneurship in the Balkans, pp.199-214, Springer, Heidelberg. 